DOI: 10.33310/2518-7813-2019-65-2-358-361

УДК 37.05: 32.097

\title{
В'ячеслав ШИНКАРЕНКО
}

кандидат педагогічних наук,

завідувач кафедри дошкільної та початкової освіти,

Комунальний заклад вищої освіти «Дніпровська академія неперервної освіти», вул. Володимира Антоновича, 70, 49006 Дніпро, Україна, e-mail: forte-pianowww@ukr.net

\section{Ольга ВИНОГРАДОВА}

старший викладач кафедри кафедри дошкільної та початкової освіти, Комунальний заклад вищої освіти "Дніпровська академія неперервної освіти», вул. Володимира Антоновича, 70, 49006 Дніпро, Україна,

e-mail: olnivin@gmail.com

\section{Людмила ПИСАРЕВА}

старший викладач кафедри кафедри дошкільної та початкової освіти, Комунальний заклад вищої освіти "Дніпровська академія неперервної освіти», вул. Володимира Антоновича, 70, 49006 Дніпро, Україна

\section{СУТНІСТЬ ПОНЯТІЙНОГО АПАРАТУ П АТРІОТИЧНОГО ВИХОВАННЯ ОСОБИСТОСТІ}

У статті здійснено аналіз понятійного апарату патріотичного виховання особистості. Обгрунтовано методологічні підходи до розгляду сутності патріотичного виховання старшокласників: гносеологічний, аксіологічний, герменевтичний, системний, антропологічний, культурологічний, етнопедагогічний, діалогічний, диференційований, діяльнісний, та технологічний підхід. 3 метою виявлення цілісної характеристики патріотичного виховання розкрито аспекти даного явища: історико-філософський, соціально-педагогічний, психолого-педагогічний, що дозволить дати цілісну характеристику даного явища.

Ключові слова: патріотичне виховання, понятійний апарат, особистість, освітній процес.

Аналіз історичної, філософської, соціологічної та психолого-педагогічної літератури демонструє, що проблема патріотичного виховання $є$ однією 3 найбільш важливих проблем життєдіяльності держави, суспільства, людини протягом всієї історії людства. Виникнення та поява патріотизму як складного соціально-психологічного феномена, було обумовлено виникненням і становленням найдавніших держав, які мали потребу в збереженні своїх природних багатств, своєї території, рідної мови, безпеки, традицій, формуванням прихильності до рідної землі. 3 моменту виникнення держав і по сьогоднішній день патріотизм відіграє важливу роль об'єднуючої й цементуючої сили не тільки національних, але і багатонаціональних об'єднань. В різні періоди історії патріотизм був щитом в боротьбі за незалежність народів, головним гаслом в руках політиків, які прагнуть розв'язувати загарбницькі війни, могутньою силою здатною запобігти вмирання етносу і забезпечити ії процвітання. Цим пояснюється незмінний інтерес науковців, політиків та простих громадян до проблеми.

Теоретичний аналіз наукової літератури засвідчив, що проблему національнопатріотичного виховання досліджували видатні дослідники класики вітчизняної педагогіки: Г. Ващенко,
О. Духнович, I. Огієнко, С. Русова, Г. Сковорода, М. Стельмахович, В. Сухомлинський, К. Ушинський та ін., сучасні вчені - А. Богуш, О. Вишневський, П. Кононенко, В. Кузь, Т. Поніманська, Ю. Руденко та ін.; психологічні аспекти висвітлені в працях I. Беха, М. Боришевського, П. Гнатенка та ін.

Велика кількість літератури, присвяченої патріотичному вихованню, спричинює ілюзію, що цей соціально-психологічний феномен вивченний, висвітлений і постає як щось очевидне.

Проте, якщо звернутися до великої кількості визначень цього нібито простого поняття, стає зрозумілим - це «відоме», більш того, певною мірою «узвичаєне» поняття містить велику кількість різних смислових нюансів та тлумачень, $\epsilon$ багатогранним і складним явищем.

3 аналізу наукової літератури стає зрозуміло, що сучасне розуміння патріотизму характеризується неоднозначністю і різноманітністю.

Багато в чому воно пояснюється розаїттям форм прояву, багатим змістом та складною природою даного явища. До тогож, проблема патріотизму та патріотичного виховання розглядається різними науковцями в різних соціальноекономічних, історичних і політичних умов, відношення до своєї Держави, не є виключенням і особиста позиція науковця до даної проблеми. 
Зміна соціальних цінностей та життєвих орієнтацій у сучасному суспільстві вимагає нового аналізу дефініції «патріотичне виховання», значення якого замовчувалося або ж розглядалося упереджено, за ознаками ідеологічних нашарувань. Саме тому необхідно відзначити, що вивчення і осмислення педагогічного досвіду минулого сприяє вирішенню проблеми патріотичного виховання сьогодні.

У логіці нашого дослідження представляється важливим аналіз методологічних підходів, які дозволяють визначити орієнтири даної роботи розглянути провідні поняття, пов'язані з патріотичним вихованням старшокласників.

Виходячи зі сказаного, наведемо основні методологічні підходи до розгляду сутності патріотичного виховання старшокласників: гносеологічний, аксіологічний, герменевтичний, системний, антропологічний, культурологічний, етнопедагогічний, діалогічний, диференційований, діяльнісний, та технологічний підхід.

Впродовж історії дефініція «патріотизм» мала різне наповнення, адже розуміли його по-різному. у Радянському Союзі визначення патріотизму було вельми заплутаним та не точним. Тривалий час у СРСР і країнах соціалістичного табору пропагувалась ідея «однобічного інтернаціоналізму», національного нігілізму, космополітизму, придушувалась національна гордість. Деформація патріотизму спричинялась також в силу недостатньої розробленості питання про взаємозв'язки патріотизму та інтернаціоналізму. Обидва ці поняття тлумачились досить абстрактно, поза реальним розвитком економіки, культури республік та інших національно-державних утворень.

Поняття «патріотизм» потребує всебічного аналізу з розкриттям його різних аспектів: історико-філософського, соціально-педагогічного, психолого-педагогічного, що дозволить дати цілісну характеристику даного явища.

Історико-філософський аспект патріотизму передбачає розгляд його як етнокультурними, економічними, суспільно-політичними та іншими характеристиками конкретного суспільства. Це положення знайшло відображення в роботах вітчизняних філософів [6, 77].

Видатні українські філософи-мислителі О. Духнович, Г. Сковорода, К. Ушинський, І. Франко, Я. Чепіга, Т. Шевченко, П. Юркевич у своїх творах визначне місце відводили патріотизму українського народу, а саме: любові до Батьківщини, до рідної мови, до свого народу, повазі до історичного минулого, формуванню національної свідомості.

Слід зазначити, що поняття патріотизм сьогодні оновлене, адже воно звільнене від ідеологіч- ного, комуністичного та патрійно-класового принципу, і включає та відображає нові тенденції реальності, та передбачає переосмислення його теоретичних основ. Адже патріотизм в оновленому виді може стати запорукою подолання негативних явищ в суспільстві, які виникають сьогодні.

Тож сучасна філософія тлумачить «патріотизм» як явище, морально-політичний принцип, зміст якого містить любов до Вітчизни, гордість за ії сучасне й минуле, відданість інтересам рідної країни та прагнення до ії захисту $[8,156]$.

У психолого-педагогічній літературі поняття «патріотизм» також трактується по-різному. Так, у «Педагогічному словнику» патріотизм визначається як «любов до Батьківщини, до свого народу», а радянський патріотизм як «почуття любові радянських людей до соціалістичної Батьківщини. Він нерозривно пов'язаний з будь-якими проявами буржуазного націоналізму, шовінізму і космополітизму» $[2,122]$.

у педагогічних дослідженнях радянського періоду також немає однозначного визначення даного поняття. Деякі вчені розглядали патріотизм як моральне почуття (В. Белорусова, Т. Ільїна, І. Огородніков, Д. Щербаков та ін.), інші (Н. Болдирєв, М. Гончаров, В. Єсіпов, Ф. Корольов, І. Тупаєв та ін.) визначали патріотизм як моральний принцип, третя група дослідників відносила патріотизм до етичних якостей (I. Мар'єнко, Н. Єгоров, А. Солдатенков, А. Янковська та ін.). Водначас Б. Воронович визначає радянський патріотизм як патріотизм нового, вищого типу, що знаходить свій вияв, насамперед, у «почутті радянської національної гордості» $[1,179]$.

Деякі вчені вважали правомірним розглядати патріотизм як сукупність почуттів, принципів $\mathrm{i}$ якостей. Так, Л. Міщенко, відзначаючи, що моральні якості особистості, які визначають їі спрямованість, поділяються на три групи, що характеризують ставлення людини до самої себе, інших людей і суспільства, до різних видів діяльності й до різних матеріальних цінностей, пропонувала розглядати патріотизм як складну, багатогранну інтегральну якість особистості, що охоплює всі три групи, виявляється у відношенні особистості до людей, суспільства, праці та інших видів діяльності $[7,4]$.

На основі психолого-педагогічного аналізу моральних якостей автор визначила радянський патріотизм як «складну інтегральну якість особистості, що виражає відношення радянської людини до інших людей, до соціалістичного суспільства, його матеріальних і духовних багатств, до різноманітних видів діяльності, до справ на користь Вітчизни» $[7,3]$.

Потрібно також відзначити, що «Українська радянська енциклопедія» трактує патріотизм як 
«одне з найглибших громадянських почуттів, змістом якого є любов до Батьківщини, відданість своєму народові, гордість за надбанням національної культури» $[9,367]$.

У сучасній педагогічній літературі виділяють щонайменше три різновиди патріотизму.

1. Етнічний патріотизм, що грунтується на почутті власної причетності до свого народу, на любові до рідної мови, культури, до власної історії тощо. Цей термін уперше використав відомий сучасний вчений-психолог I. Кон, який писав, що «...етнопатріотизм пов'язаний з утвердженням конкретизованих, спрощених образів свого народу, як правило, наділених позитивними рисами» $[5,189]$.

Більш детально розглядає етнопатріотизм соціолог Т. Ісламшина. Вона визначає його як почуття внутрішнього духовного зв'язку зі своїм народом, поваги до «своїх» етнічних цінностей $[4,26]$.

2. Територіальний патріотизм базується на любові до того місця на землі (до місцевості, ландшафту, клімату тощо), де людина народилася.

3. Державний патріотизм грунтується на остаточній меті нації - побудові власної держави, державному самовизначенні, державницькому світогляді та державницькому почутті; це вищий патріотизм, який базується на державній ідеології та пов'язаний 3 почуттям громадянськості $[4,115]$.

Таким чином патріотичні почуття українського народу $\epsilon$ емоційним аспектом національного державницького світогляду, що включає почуття належності до України, її історії, віру в майбутнє своєї держави. Найвищою формою патріотизму виступає почуття любові до Батьківщини, готовність терпіти муки й навіть іти на смерть заради неї.

У світлі нашого дослідження доцільно зважувати той факт, що сучасне розуміння патріотизму також характеризується неоднозначністю і різноманітністю. Багато в чому воно пояснюється багатим змістом його розмаїття. До того ж патріотизм розглядається різними дослідниками в різних економічних, політичних, соціально-педагогічних та історичних умовах, від власної позиції науковця, його відношення до Держави та своєї Вітчизни, від багажу знань в різних сферах.

У наукових дослідженнях Ю. Зубцової визначено, що тісно пов'язані у структурі особистості три групи патріотичних якостей:

1) якості, що характеризують ціннісне ставлення особистості до своєї сім'ї, родини;

2) якості, що визначають моральне ставлення до людей, толерантне ставлення до інших культур та націй;
3) якості, що характеризують ставлення до своєї країни, рідного краю.

Базовими патріотичними якостями визначено:

- любов і повага до батьків, своєї родини, відчуття гордості за свій рід;

- ціннісне ставлення до Батьківщини, рідного краю;

- толерантне ставлення до людей інших національностей, поважне

- ставлення до їхньої культури та традицій;

- усвідомлення себе частиною українського народу $[3,12]$.

Тож хочемо зазначити, що характеристика в цілісному вигляді даного поняття складається 3 декількох складових. У соціально-педагогічному аспекті розглядали патріотизм як ставлення особистості до Батьківщини, як соціально-моральну цінність. У психолого-педагогічному аспекті патріотизм розглядався як моральна складна якість. у філософському аспекті науковці розглядали патріотизм як наявність «природних» основ, що відображають варіативну та інваріативну характеристики даного явища.

У зв'язку 3 цим визначення поняття «патріотизм» в сучасних умовах має, на наш погляд, спиратися на філософські, психолого-педагогічні та соціальні положення, що відображають специфіку даного поняття, враховує процеси демократизації та деполітизації педагогічної науки і системи освіти, посилення особистісного аспекту у виховній роботі з підростаючим поколінням. Все це обумовлює відмову від таких складових, як відданість справі комунізму, співдружності соціалістичних країн, непримиренність до ворогів соціалістичної держави тощо.

На нашу думку це ні в якому разі не означає, що патріотизм треба розглядати поза політичних, соціально-економічних, суспільно-історичних умов. Неправомірним також було б заперечувати соціальну характеристику даного феномена, до того ж знаючи, що це закладено в понятті «Вітчизна». Тож на нашу думку цілком правомірним $\epsilon$ включення в зміст поняття патріотизм всіх складових, що характеризують відношення людини до суспільства, в якому вона живе.

На основі положень філософської та психолого-педагогічної літератури констатовано, що зміст понять «патріотизм» визначається як орієнтування на високу моральну якість яка орієнтується на найвищі людські взірці, дотримується принципів природовідповідності, культуровідповідності підростаючого покоління, та виховує в нього любов до Батьківщини. 


\section{Список використаних джерел}

1. Воронович Б. Філософський аналіз структури практики / Б. Воронович. - М. : Думка, 1972. - 279 с.

2. Гончаренко С. У. Український педагогічний словник / С. У. Гонський Київ. : Либідь 1997. - 366 с.

3. Зубцова Ю. Є. Формування патріотичних якостей молодших школярів у взаємодії школи та сім'ї / Зубцова Юлія Євгенівна - Авторф.дис.канд.пед.наук.-13.00.07 - теорія і методика виховання. - К., 2012. - 21 с.

4. Исламшина Т. Г. Кризис полиэтнического общества и возрождение этнических ценностей. Автореф. дисс... докт. социал. наук, - Уфа, 1993. - 38 с.

5. Кон И. С. Психология предрассудка // Новый мир. - 1969. - № 9. - С.186-193.

6. Кульчицький В. Й. Філософсько-світоглядні передумови розвитку патріотичного виховання в Україні (історичний аспект) / В. Й. Кульчицький // Науковий вісник Ужгородського національного університету. Серія педагогіка і соціальна робота. - 2013. - № 30. - С. 76-78.

7. Міщенко Н. Який же проросте патріотизм? / Н. Міщенко // Рідна школа. - 2004. - № 1. - С. 1-8.

8. Патріотизм: філософський словник / за ред. В. І. Шинкарука. - 2-ге вид., перероб. і доповн. - К., 1986. - 358 с.

9. Українська радянська енциклопедія / [М. П. Бажан, Ф. С. Бабичев, О. К. Антонов та ін.]. - К. : Поліграфкнига, 1982. T. 8. -527 c.

\section{References}

1. Voronovich B. (1972). Philosophical analysis of the structure of practice. Moscow: Thought, 279 [in Russian].

2. Goncharenko S. U. (1997). Ukrainian Pedagogical Dictionary. Kyiv: Lybid, 366 [in Ukrainian].

3. Zubtsova Yu. E. (2012). Formation of patriotic qualities of junior pupils in the interaction of school and family. [Author.dis.kand.ped.nauc]. -13.00.07 - Theory and methodology of education. - Kyiv. 21 [in Ukrainian].

4. Islamshina T. G. (1993). The crisis of a polyethnic society and the revival of ethnic values. Author's abstract. dis ... doc. social Sciences. Ufa: 38 [in Russian].

5. Kon I. S. (1969). Psychology of prejudice [New World]. No. 9. - P. 186-193. [in Russian].

6. Kulchytskyy V. Y. (2013). Philosophical-ideological prerequisites for the development of patriotic education in Ukraine (historical aspect). Scientific Bulletin of Uzhgorod National University. Series of pedagogy and social work. P. 76-78. [in Ukrainian].

7. Mishchenko N. (2004). What kind of germinate patriotism? Native school. P. 1-8. [in Ukrainian].

8. Shynkaruk. V. I. (1986). Patriotism. Philosophical Dictionary. 2nd form., Processing. and complemented - Kyiv. 358 [in Ukrainian].

9. Bazhan. P. Ukrainian Soviet Encyclopedia (1982). - Kyiv: Polygraphbook. Vol. 8. 527 [in Ukrainian].

\section{Вячеслав Шинкаренко, Ольга Виноградова, Людмила Писарева. Сущность понятийного аппа- рата патриотического воспитания личности}

В статье осуществлен анализ понятийного аппарата патриотического воспитания личности. Обоснованно методологические подходы к рассмотрению сущности патриотического воспитания старшеклассников: гносеологический, аксиологический, герменевтический, системный, антропологический, культурологический, етнопедагогичних, диалогический, дифференцированный, деятельностный и технологический подход. С целью выявления целостной характеристики патриотического воспитания раскрыто аспекты данного явления: историко-философский, социально-педагогический, психологопедагогический, что позволит дать целостную характеристику данного явления.

Ключевые слова: патриотическое воспитание, понятийный аппарат, личность, образовательный процесс.

Vyacheslav Shynkarenko, Olga Vinogradova, Lyudmila Pisareva. The essence of the conceptual apparatus of the patriotic upbringing of the individual

The article analyzes the conceptual apparatus of patriotic education of the person. The methodological approaches to the consideration of the essence of patriotic education of senior pupils are grounded: epistemological, axiological, hermeneutical, systemic, anthropological, cultural, ethnopedagogical, dialogical, differentiated, activity and technological approaches. In order to identify the integral characteristics of patriotic education, the aspects of this phenomenon are revealed: historical and philosophical, socio-pedagogical, psychological and pedagogical, which will give a complete description of this phenomenon. Three types of patriotism are distinguished: Ethnic patriotism, based on the feeling of its own affiliation with its people, on love to the native language, culture, to their own history, etc.; territorial patriotism is based on the love of that place on earth (to the terrain, landscape, climate, etc.), where the person was born; state patriotism is based on the ultimate goal of the nationthe construction of its own state, state self-determination, the state's outlook and state feeling; This is a higher patriotism, based on state ideology and associated with a sense of citizenship. Groups that are closely linked in the structure of the personality of the patriotic qualities are defined: qualities characterizing the value attitude of the individual to his family and family; qualities that determine moral attitudes towards people, tolerant attitudes towards other cultures and nations; qualities characterizing the attitude towards their country, native land, the basic patriotic qualities of which are determined (love and respect for parents, their families, a sense of pride in their race, value attitude towards the Motherland, native land, tolerant attitude to people of other nationalities, respectful attitude to their culture and traditions, to realize themselves as part of the Ukrainian people.

Keywords: patriotic upbringing, conceptual apparatus, personality, educational process. 